\title{
ANALISIS BIAYA TERHADAP PENDAPATAN USAHATANI KAKAO DI KECAMATAN INDRA MAKMUR KABUPATEN ACEH TIMUR
}

\author{
Rozalina ${ }^{1}$, Gufran Nurdila ${ }^{2}$ \\ ${ }^{I}$ Dosen Fakultas Pertanian Universitas Samudra \\ ${ }^{2}$ Mahasiswa Program Studi Agribisnis Fakultas Pertanian Universitas Samudra
}

\begin{abstract}
Abstrak
Tujuan dari penelitian ini adalah untuk mengetahui pengaruh biaya produksi terhadap pendapatan usahatani kakao di Kecamatan Indra Makmur Kabupaten Aceh Timur. Metode penelitian yang digunakan dalam penelitian ini adalah metode survei (survey method). Objek penelitian ini adalah usahatani kakao di Kecamatan Indra Makmur Kabupaten Aceh Timur. Analisis faktor-faktor yang mempengaruhi pendapatan usahatani kakao dilakukan dengan menggunakan persamaan regresi linier sederhana dengan menggunakan SPSS 17 satu variabel bebas yaitu variabel biaya produksi dan satu variabel terikat adalah pendapatan usahatani kakao. Hasil analisis diperoleh persamaan regresi yaitu: $\mathrm{Y}=59,606-0,446 \mathrm{X} 1$

Hasil perhitungan diperoleh $\mathrm{R} 2=0,06$ atau $6 \%$ menyatakan bahwa biaya produksi berpengaruh terhadap pendapatan usahatani kakao di Kecamatan Indra Makmur. $94 \%$, faktor lain yang sangat dominan mempengaruhi pendapatan yang tidak diteliti dalam penelitian ini. Hasil pengujian Uji t menjelaskan bahwa variabel biaya produksi secara Parsial tidak berpengaruh dan negatif terhadap variabel pendapatan petani kakao di Kecamatan Indra Makmur
\end{abstract}

Kata kunci : Usahatani, biaya dan pendapatan

\section{Pendahuluan}

Kakao merupakan salah satu komoditi unggulan sektor non migas di Indonesia. Pengusahaan kakao di Indonesia sebagian besar merupakan perkebunan rakyat di desa-desa yang tersebar di hampir seluruh provinsi mulai dari Aceh, Lampung, Jawa timur, Bali, NTT, Sulawesi sampai dengan Papua sehingga agribisnis kakao secara langsung berkesinambungan dengan kesejahteraan masyarakat kecil di pedesaan. Menurut data dari Badan Pusat Statistik Propinsi Aceh tahun 2015, produksi kakao di Kabupaten Aceh Timur sebesar 6.536 ton. Produksi komoditas tersebut merupakan hasil dari perkebunan rakyat yang dikelola rumah tangga, belum termasuk perusahaan perkebunan yang mengelola lahan secara besarbesaran. Produksi kakao di Aceh Timur merupakan yang terbesar kedua di Propinsi Aceh setelah Kabupaten Aceh Tenggara. Kabupaten Aceh Tenggara memiliki luas lahan perkebunana kakao seluas 19.454 hektar dengan produksi

8.843 ton, sedangkan Kabupaten Aceh Timur memiliki luas lahan kakao seluas 12.416 hektar dengan produksi 6.536 ton.

Pada umumnya tujuan petani melakukan kegiatan usahatani ialah untuk memperoleh keuntungan. Petani juga harus memperhitungkan faktor apa saja yang dapat mempengaruhi pendapatan atau keuntungannnya dalam berusahatani. Dalam suatu usahatani pasti membutuhkan biaya untuk menunjang proses produksi tersebut. Biaya produksi yakni biaya-biaya yang berhubungan langsung dengan produksi dari suatu produk akan dipertemukan dengan penghasilan (revenue) di periode mana produk itu dijual (Halim, 2000). Biaya produksi dalam berusahatani terbagi atas biaya tetap dan biaya tidak tetap. Biaya produksi akan mempengaruhi pendapatan yang didapatkan petani dalam berusahatani. 
Keadaaan perkebunan kakao di Kecamatan Indra Makmur Kabupaten Aceh Timur sangat memungkinkan untuk dikembangkan lebih baik lagi. Namun saat ini belum ada informasi bagi petani kakao tentang faktor faktor apa saja yang mempengaruhi pendapatan usahatani kakao. Oleh karena itu penulis tertarik untuk melaksanakan penelitian mengenai faktor biaya yang mempengaruhi pendapatan usahatani kakao Theobroma cacao, L) di Kecamatan Indra Makmur Kabupaten Aceh Timur.

\section{Tujuan Penelitian}

Untuk mengetahui pengaruh biaya produksi terhadap pendapatan usahatani kakao di Kecamatan Indra Makmur Kabupaten Aceh Timur.

\section{Hipotesis}

Biaya produksi berpengaruh terhadap pendapatan usahatani kakao di Kecamatan Indra Makmur Kabupaten Aceh Timur.

\section{Metodologi Penelitian}

Penelitian ini dilaksanakan di Kecamatan Indra Makmur Kabupaten AcehTimur dengan menggunakan metode survei. Penelitian survei adalah penelitian yang mengambil sampel dari satu populasi dan menggunakan kuisioner sebagai alat pengumpulan data yang pokok. Musa (2008:18), survei memiliki arti pengamatan/penyelidikan yang kritis untuk mendapatkan keterangan yang jelas dan baik terhadap suatu persoalan di dalam suatu daerah tertentu.

Objek penelitian ini adalah petani yang melakukan usahatani kakao di Kecamatan Indra Makmur Kabupaten Aceh Timur. Ruang lingkup penelitian dibatasi pada biaya produksi, produksi dan harga jual kakao. Penelitian dilaksanakan pada bulan Oktober hingga Desember 2017.

\section{Populasi dan Sampel}

Pemilihan lokasi penelitian ditentukan dengan metode purposive sampling (sengaja) berdasarkan pertimbangan- pertimbangan tertentu". Kecamatan Indra Makmur terdiri atas 13 desa dan hanya 8 desa saja yang memiliki usahatani kakao. Desa yang dijadikan sampel dalam penelitian ini berjumlah 5 yaitu Desa Seuneubok Bayu, Jambu Lubok, Jambo Bale, Blang Nisam dan Desa Alue Patong, dengan alasan pada ke-5 desa tersebut yang memiliki petani usahatani kakao terbesar. Populasi dalam penelitian ini adalah seluruh petani kakao di 5 desa sampel. Jumlah populasi petani kakao di 5 desa sampel adalah 62 orang. Penentuan sampel petani pada penelitian ini menggunakan metode SimpleRandom Sampling. Jumlah sampel petani yang diambil dari masing-masing desa adalah $50 \%$ dari populasi, sehingga jumlah sampel dalam penelitian ini adalah 31 sampel.

\section{Metode Pengumpulan Data}

Pengumpulan data dalam penelitian ini di lakukan dengan cara Observasi, wawancara dan Quisioner serta pengumpulan dari literatur terkait. Data yang diperoleh berupa data primer dan data sekunder.

\section{Variabel Data yang Dianalisis}

1. Data dianalisis meliputi biaya produksi, adalah besarnya biaya-biaya yang dikeluarkan petani dalam usahatani kakao selama setahun, dihitung dalam satuan rupiah/tahun dan pendapatan usahatani skakao.

2. Produksi, adalah banyaknya kakao yang dihasilkan dari usahatani selama setahun, dihitung dalam satuan kilogram/tahun.

3. Harga jual, adalah rata-rata harga jual kakao, dihitung dalam satuan rupiah/kilogram.

4. Pendapatan, adalah penerimaan yang diperoleh petani kakao selama setahun setelah dikurangi biaya-biaya yang dikeluarkan, dihitung dalam satuan rupiah/tahun. 
Metode Analisis Data

Analisis Pendapatan

Soekartawi (2002:43), analisis pendapatan secara matematis dapat dirumuskan sebagai berikut:

$\mathrm{Pd}=\mathrm{TR}-\mathrm{TC}$

$\mathrm{TR}=\mathrm{Y}$. Py

$\mathrm{TC}=\mathrm{FC}+\mathrm{VC}$

Keterangan:

$\mathrm{Pd}$ : Pendapatan usahatani (Rp/Tahun)

TR : Total Revenue/total penerimaan ( $\mathrm{Rp} /$ Tahun)

TC : Total Cost/ total biaya (Rp/ Tahun)

FC : Fixed Cost/biaya tetap (Rp/ Tahun)

$\mathrm{VC}$ : Variable Cost/biaya variabel (Rp/ Tahun)

$\mathrm{Y}$ : Yield/Produksi yang diperoleh dari usahatani (Kg/ Tahun)

Py : Harga Y $(\mathrm{Rp} / \mathrm{Kg})$

\section{Analisis Biaya yang Mempengaruhi Pendapatan Usahatani Kakao}

Data yang dikumpulkan dari lapangan baik data primer maupun sekunder diolah dengan mentabulasikan dan kemudian dipindahkan dalam bentuk tabelaris sesuai dengan kebutuhan analisi. Model yang digunakan untuk pengujian hipotesis dalam penelitian ini adalah regresi linier sederhana dan diselesaikan dengan menggunakan program SPSS 17. Analisis ini digunakan untuk mengetahui arah hubungan antara variabel bebas dengan variabel terikat. Hubungan tersebut bisa positif atau negatif dan untuk memprediksi nilai dari variabel terikat dapat ditulis sebagai berikut:

$\mathrm{Y}=\mathrm{a} 0+\mathrm{a} 1 \mathrm{X} 1+\mathrm{e}$

(Sudjana, 2005)

Dimana:

$\mathrm{Y}:$ Pendapatan (Rp/ Tahun)

a0 : Intercept

a1 $=$ Koefisien regresi

$\mathrm{e}=$ error

2. Koefisien determinasi (R2) bertujuan untuk mengetahui seberapa besar pengaruh variabel independen menjelaskan variabel dependen. Besarnya R Square berkisar antara 0 -
1. Semakin mendekati satu berarti semakin kuat pengaruhnya.

\section{Uji Parsial (Uji t)}

Uji secara parsial (Uji t) bertujuan untuk mengetahui besarnya pengaruh variabel independen secara individual (parsial) terhadap variabel dependen.

4. T hitung $>$ ttabel pada $\alpha=5 \%$ dan $\alpha=1$ $\%$ artinya ada pengaruh biaya terhadap pendapatan usahatani kakao di kecamatan indra makmur kabupaten Aceh Timur

T hitung $<$ ttabel pada $\alpha=5 \%$ artinya tidak ada pengaruh biaya terhadap pendapatan usahatani kakao di kecamatan indra makmur kabupaten Aceh Timur.

\section{Hasil Dan Pembahasan}

Kecamatan Indra Makmur merupakan salah satu kecamatan yang ada di Kabupaten Aceh Timur yang memiliki luas wilayah sebesar $89,05 \mathrm{~km} 2$ atau sekitar 1,47 persen dari luas Kabupaten Aceh Timur. Secara astronomis Kecamatan Indra Makmur berada pada koordinat $04^{\circ} 31^{\prime} 51,35^{\prime \prime}$ - 0459'12,16" Lintang Utara dan antara 97 $31^{\prime} 48,65^{\prime \prime}$ 97³9'56,75" Bujur Timur. Kecamatan Indra Makmur terbagi atas 13 desa. Pusat pemerintahan Kecamatan Indra

Makmur berada di Desa Alue Ie Mirah. Seluruh desa di wilayah Kecamatan Indra Makmur merupakan daerah bukan pantai dengan rata-rata ketinggian di bawah 50 meter di atas permukaan laut. Topografi wilayah Kecamatan Indra Makmur adalah dataran, dengan ketinggian rata rata berkisar antara 10-100 meter dari permukaan laut. Kecamatan Indra Makmur termasuk dalam iklim tropis dengan suhu udara rata rata berkisar antara $26^{\circ}-30^{\circ} \mathrm{C}$.

\section{Biaya Produksi}

Biaya produksi yang dikeluarkan petani kakao meliputi biaya tetap dan biaya variabel. Biaya tetap yang dikeluarkan petani adalah biaya sewa lahan dan biaya 
penyusutan peralatan, dihitung dalam satuan rupiah per tahun (Rp/Tahun). Biaya variabel yang dikeluarkan meliputi biaya pembelian bibit kakao, biaya tenaga kerja, dan biaya pembelian pupuk dan pestisida. Rata-rata biaya produksi (biaya tetap dan biaya variabel) usahatani kakao di Kecamatan Indra Makmur dapat dilihat pada Tabel 1, Tabel 2 dan Tabel 3 berikut ini.

Tabel 1 Rata-rata Biaya Tetap per Usahatani Kakao di Kecamatan Indra Makmur, 2017

\begin{tabular}{|c|l|l|c|c|}
\hline No & Desa Sampel & $\begin{array}{c}\text { Sewa Lahan } \\
(\text { Rp/Tahun })\end{array}$ & $\begin{array}{c}\text { Biaya Penyusutan } \\
(\text { Rp/Tahun })\end{array}$ & $\begin{array}{c}\text { Biaya Tetap } \\
\text { (Rp/Tahun) }\end{array}$ \\
\hline 1 & Seuneubok Bayu & 1.833 .333 & 212.828 & 2.096 .161 \\
2 & Jambo Lubok & 2.100 .000 & 202.680 & 2.302 .680 \\
3 & Jambo Bale & 2.000 .000 & 201.907 & 2.201 .907 \\
4 & Blang Nisam & 2.125 .000 & 190.583 & 2.315 .583 \\
5 & Alue Patong & 2.000 .000 & 215.129 & 2.215 .129 \\
\hline \multicolumn{2}{|c|}{ Rata-rata } & 2.025 .806 & 204.209 & 2.230 .015 \\
\hline
\end{tabular}

Sumber : Data Primer (diolah), 2018

Dari Tabel 1 di atas sewa lahan ratarata adalah Rp. 2.025.806, dengan biaya sewa lahan tertinggi di Desa Blang Nisam yaitu sebesar Rp. 2.125.000 dan terendah di Desa Seuneubok Bayu yaitu sebesar Rp. 1.833.333. Biaya penyusutan rata-rata adalah $\mathrm{Rp}$. 204.209, dengan biaya tertinggi di Desa
Alue Patong sebesar Rp. 215.129 dan terendah di Desa Blang Nisam sebesar Rp. 190.853. Rata-rata biaya tetap adalah Rp. 2.230.015 dengan biaya tetap tertinggi di Desa Blang Nisam sebesar Rp. 2.215.129 dan terendah di Desa Seuneubok Bayu yaitu sebesar Rp. 2.096.161.

Tabel 2 Rata-rata Biaya Variabel per Usahatani Kakao di Kecamatan Indra Makmur, 2017

\begin{tabular}{|c|l|c|c|c|}
\hline No & \multicolumn{1}{|c|}{ Desa Sampel } & $\begin{array}{c}\text { Tenaga Kerja } \\
\text { (Rp/Tahun) }\end{array}$ & $\begin{array}{c}\text { Pupuk dan } \\
\text { Pestisida } \\
\text { (Rp/ Tahun) }\end{array}$ & $\begin{array}{c}\text { Biaya Variabel } \\
\text { (Rp/ Tahun) }\end{array}$ \\
\hline 1 & Seuneubok Bayu & 2.889 .130 & 715.653 & 3.604 .783 \\
2 & Jambo Lubok & 2.766 .250 & 711.875 & 3.478 .125 \\
3 & Jambo Bale & 2.685 .000 & 609.167 & 3.294 .167 \\
4 & Blang Nisam & 2.681 .250 & 635.193 & 3.316 .443 \\
5 & Alue Patong & 2.722 .321 & 656.875 & 3.379 .196 \\
\hline \multicolumn{2}{|l|}{ Rata-rata } & 2.745 .074 & 663.832 & 3.408 .906 \\
\hline
\end{tabular}

Sumber : Data Primer (diolah), 2018

Dari Tabel 2 di atas terlihat ratarata biaya tenaga kerja untuk Kecamatan Indra Makmur adalah sebesar Rp. 2.745.074. Rata-rata biaya sarana produksi yang terdiri dari pupuk dan pestisida, sebesar Rp. 663.832, dan rata-rata biaya variabel sebesar Rp. 3.408.906, dengan penggunaan biaya variabel tertinggi untuk bibit, pupuk dan pestisida. 
Tabel 3 Rata-rata Biaya Produksi Kakao di Kecamatan Indra Makmur, 2017

\begin{tabular}{|c|c|c|c|c|}
\hline No & Desa Sampel & $\begin{array}{l}\text { Biaya Tetap } \\
\text { (Rp/Tahun) }\end{array}$ & $\begin{array}{c}\text { Biaya Variabel } \\
\text { (Rp/ Tahun) }\end{array}$ & $\begin{array}{c}\text { Biaya Produksi } \\
\text { (Rp/ Tahun) }\end{array}$ \\
\hline 1 & \multirow{5}{*}{$\begin{array}{l}\text { Seuneubok Bayu } \\
\text { Jambo Lubok } \\
\text { Jambo Bale } \\
\text { Blang Nisam } \\
\text { Alue Patong }\end{array}$} & 2.096 .161 & 3.604 .783 & 5.700 .944 \\
\hline 2 & & 2.302 .680 & 3.478 .125 & 5.780 .805 \\
\hline 3 & & 2.201 .907 & 3.294 .167 & 5.496 .073 \\
\hline 4 & & 2.315 .583 & 3.316 .443 & 5.632 .026 \\
\hline 5 & & 2.215 .129 & 3.379 .196 & 5.594 .325 \\
\hline \multicolumn{2}{|r|}{ Rata-rata } & 2.230 .015 & 3.408 .906 & 5.638 .921 \\
\hline
\end{tabular}

Sumber : Data Primer (diolah), 2018

Dari Tabel 3 di atas terlihat bahwa rata-rata biaya produksi usahatani kakao dalam satu tahun di Kecamatan Indra Makmur adalah sebesar Rp.5.638.921/Tahun. Biaya produksi tertinggi di Desa Jambo Lubok sebesar Rp.5.780.805/Tahun dan terendah di Desa Jambo Bale sebesar Rp. 5.496.073/Tahun.

\section{Produksi dan Nilai Hasil Produksi}

Produksi kakao setiap petani berbeda-beda antara lain tergantung luas lahan usahatani dan perawatan yang dilakukan petani. Produksi kakao dalam penelitian ini merupakan hasil panen kakao yang diperoleh petani dalam satu tahun yang dihitung dalam satuan kilogram per tahun (Kg/Tahun). Hasil produksi rata-rata kakao di Kecamatan Indra Makmur pada saat penelitian dilaksanakan dapat dilihat pada Tabel 4 berikut ini.

Tabel 4 Rata-rata Produksi Kakao di Kecamatan Indra Makmur, 2017

\begin{tabular}{|c|l|c|}
\hline No & \multicolumn{1}{|c|}{ Desa Sampel } & Rata-Rata Produksi Kakao (Kg/Tahun) \\
\hline 1 & Seuneubok Bayu & 3.042 \\
2 & Jambo Lubok & 3.063 \\
3 & Jambo Bale & 3.149 \\
4 & Blang Nisam & 3.094 \\
5 & Alue Patong & 3.166 \\
\hline \multicolumn{2}{|c|}{ Rata-rata } & 3.104 \\
\hline
\end{tabular}

Sumber: : Data Primer (diolah), 2018

Dari tabel 4 terlihat bahwa produksi rata-rata kakao di Kecamatan Indra Makmur adalah sebesar 3.104 $\mathrm{Kg}$ /Tahun. Rata-rata produksi kakao per hektar tertinggi di Desa Alue Patong yaitu sebesar 3.166 $\mathrm{Kg} / \mathrm{Tahun}$, dan terendah di Desa Seuneubok Bayu yaitu sebesar $3.042 \mathrm{Kg} /$ Tahun.
Nilai hasil produksi merupakan perkalian produksi dengan harga jual. Dalam penelitian ini produksi adalah produksi yang didapatkan petani kakao dalam satu tahun, sedangkan harga jual adalah harga yang berlaku pada saat penelitian. Rata-rata nilai hasil produksi dapat dilihat pada Tabel 5 berikut ini. 
Tabel 5 Nilai Hasil Produksi Kakao di Kecamatan Indra Makmur, 2017

\begin{tabular}{|l|l|c|}
\hline No & \multicolumn{1}{|c|}{ Desa Sampel } & Nilai Hasil Produksi (Rp/Tahun) \\
\hline 1 & Seuneubok Bayu & 63.333 .333 \\
2 & Jambo Lubok & 61.375 .000 \\
3 & Jambo Bale & 64.229 .000 \\
4 & Blang Nisam & 62.187 .500 \\
5 & Alue Patong & 62.730 .714 \\
\hline \multicolumn{2}{|c|}{ Rata-rata } \\
\hline
\end{tabular}

Sumber: : Data Primer (diolah), 2018

Dari Tabel 5 di atas terlihat bahwa rata-rata nilai hasil produksi kakao di Kecamatan Indra Makmur adalah sebesar Rp. 62.730.161/Tahun. Nilai hasil produksi tertinggi di Desa

Jambo Bale sebesar Rp. 64.229.000/Tahun. Sedangkan nilai hasil produksi terendah di Desa Jambo Lubok yaitu sebesar Rp.61.375.000/Tahun

Pendapatan Usahatani Kakao

Jumlah pendapatan usahatani kakao didapatkan dari jumlah penerimaan (nilai hasil produksi) dikurangi dengan biaya produksi usahatani. Penerimaan merupakan hasil kali biaya produksi dengan harga jual kakao. Sedangkan biaya produksi merupakan penjumlahan biaya tetap (fixed cost) dan biaya tidak tetap (variable cost). Rata-rata pendapatan usahatani kakao di Kecamatan Indra Makmur dapat dilihat pada Tabel 6 .

Tabel 6 Rata-rata Pendapatan Usahatani Kakao di Kecamatan Indra Makmur, 2017

\begin{tabular}{|c|l|c|}
\hline No & \multicolumn{1}{|c|}{ Desa Sampel } & Pendapatan Usahatani (Rp/Tahun) \\
\hline 1 & Seuneubok Bayu & 57.632 .389 \\
2 & Jambo Lubok & 55.594 .195 \\
3 & Jambo Bale & 58.732 .927 \\
4 & Blang Nisam & 56.555 .474 \\
5 & Alue Patong & 57.136 .389 \\
\hline \multicolumn{2}{|c|}{ Rata-rata } \\
\hline
\end{tabular}

Sumber: : Data Primer (diolah), 2018

Dari Tabel 6 di atas terlihat bahwa rata-rata pendapatan usahatani kakao di Kecamatan Indra Makmur adalah Rp. 57.091.241/Tahun. Rata-rata pendapatan tertinggi di Desa Jambo Bale sebesar Rp. 58.732.927/Tahun dan terendah di Desa Jambo Lubok sebesar Rp. 55.594.195/Tahun. Hal ini sesuai dengan nilai hasil produksi yang didapatkan di Desa Jambo Bale merupakan nilai hasil produksi tertinggi, sedangkan di Desa Jambo Lubok merupakan nilai hasil produksi terendah.

\section{Produksi dan Nilai Hasil Produksi}

Produksi kakao setiap petani berbedabeda antara lain tergantung luas lahan usahatani dan perawatan yang dilakukan petani. Produksi kakao dalam penelitian ini merupakan hasil panen kakao yang diperoleh petani dalam satu tahun yang dihitung dalam satuan kilogram per tahun 
(Kg/Tahun). Hasil produksi rata-rata kakao di Kecamatan Indra Makmur pada saat penelitian dilaksanakan dapat dilihat pada Tabel 7 berikut ini.

Tabel 7 Rata-rata Produksi Kakao di Kecamatan Indra Makmur, 2017

\begin{tabular}{|c|l|c|}
\hline & \multicolumn{1}{|c|}{ Desa Samoel } & Rata-Rata Produksi Kakao (Ko/Tahun) \\
\hline 1 & Seuneubok Bayu & 3.042 \\
2 & Jambo Lubok & 3.063 \\
3 & Jambo Bale & 3.149 \\
4 & Blang Nisam & 3.094 \\
5 & Alue Patong & 3.166 \\
\hline \multicolumn{2}{|c|}{ Rata-rata } & 3.104 \\
\hline
\end{tabular}

Sumber: : Data Primer (diolah), 2018

Dari tabel di atas terlihat bahwa produksi rata-rata kakao di Kecamatan Indra Makmur adalah sebesar 3.104 $\mathrm{Kg}$ /Tahun. Rata-rata produksi kakao per hektar tertinggi di Desa Alue Patong yaitu sebesar $3.166 \mathrm{Kg} / \mathrm{Tahun}$, dan terendah di Desa Seuneubok Bayu yaitu sebesar $3.042 \mathrm{Kg} / \mathrm{Tahun}$.
Nilai hasil produksi merupakan perkalian produksi dengan harga jual. Dalam penelitian ini produksi adalah produksi yang didapatkan petani kakao dalam satu tahun, sedangkan harga jual adalah harga yang berlaku pada saat penelitian. Rata-rata nilai hasil produksi dapat dilihat pada Tabel 8 berikut ini.

Tabel 8 Nilai Hasil Produksi Kakao di Kecamatan Indra Makmur, 2017

\begin{tabular}{|c|l|c|}
\hline No & \multicolumn{1}{|c|}{ Desa Sampel } & Nilai Hasil Produksi (Rp/Tahun) \\
\hline 1 & Seuneubok Bayu & 63.333 .333 \\
2 & Jambo Lubok & 61.375 .000 \\
3 & Jambo Bale & 64.229 .000 \\
4 & Blang Nisam & 62.187 .500 \\
5 & Alue Patong & 62.730 .714 \\
\hline \multicolumn{2}{|c|}{ Rata-rata } & 62.730 .161 \\
\hline
\end{tabular}

Sumber : Data Primer (diolah), 2018

Dari Tabel 8 di atas terlihat bahwa rata-rata nilai hasil produksi kakao di Kecamatan Indra Makmur adalah sebesar Rp. 62.730.161/Tahun. Nilai hasil produksi tertinggi di Desa Jambo Bale sebesar Rp. 64.229.000/Tahun. Sedangkan nilai hasil produksi terendah di Desa Jambo Lubok yaitu sebesar Rp.61.375.000/Tahun.

\section{Pendapatan Usahatani Kakao}

Jumlah pendapatan usahatani kakao didapatkan dari jumlah penerimaan (nilai hasil produksi) dikurangi dengan biaya produksi usahatani. Penerimaan merupakan hasil kali biaya produksi dengan harga jual kakao. Sedangkan biaya produksi merupakan penjumlahan biaya tetap (fixed cost) dan biaya tidak tetap (variable cost). Rata-rata pendapatan usahatani kakao di Kecamatan Indra Makmur dapat dilihat pada Tabel 9 berikut ini. 
Tabel 9 Rata-rata Pendapatan Usahatani Kakao di Kecamatan Indra Makmur, 2017

\begin{tabular}{|c|l|c|}
\hline No & \multicolumn{1}{|c|}{ Desa Sampel } & Pendapatan Usahatani (Rp/Tahun) \\
\hline 1 & Seuneubok Bayu & 57.632 .389 \\
2 & Jambo Lubok & 55.594 .195 \\
3 & Jambo Bale & 58.732 .927 \\
4 & Blang Nisam & 56.555 .474 \\
5 & Alue Patong & 57.136 .389 \\
\hline \multicolumn{2}{|c|}{ Rata-rata } & 57.091 .241 \\
\hline
\end{tabular}

Sumber : : Data Primer (diolah), 2018

Dari Tabel 9 di atas terlihat bahwa rata-rata pendapatan usahatani kakao di Kecamatan Indra Makmur adalah Rp. 57.091.241/Tahun. Ratarata pendapatan tertinggi di Desa Jambo Bale sebesar Rp. 58.732.927/Tahun dan terendah di Desa Jambo Lubok sebesar Rp. 55.594.195/Tahun. Hal ini sesuai dengan nilai hasil produksi yang didapatkan di Desa Jambo Bale merupakan nilai hasil produksi tertinggi, sedangkan di Desa Jambo Lubok merupakan nilai hasil produksi terendah.

\section{Pengaruh Biaya Produksi (X1) Terhadap Pendapatan}

Untuk mengetahui pengaruh variabel bebas yaitu biaya produksi (X1), terhadap variabel terikat yaitu pendapatan usahatani (Y) dilakukan analisis terhadap data yang didapatkan digunakan adalah analisis linier sederhana Analisis linier ini dilakukan untuk mendapatkan nilai koefisien regresi dari variabel bebas biaya produksi Dari analisis regresi di peroleh $\mathrm{Y}=59,606-0,446 \mathrm{X}$ artinya setiap kenaikan satu juta rupiah biaya produksi akan mengakibatkan penurunan pendapatan sebesar Rp.446.000.

Hasil analisis uji $\mathrm{t}$ diperoleh $\mathrm{t}$ hitung $=-0,429$ dengan tingkat significan 0,671 artinya $>$ dari 0,05. Hasil analisis uji $t$ menunjukkan biaya idak berpengaruh terhadap pendapatan usahatani kakao di
Kecamatan Indra Makmur Kabupaten Aceh Timur.

Hasil analisis Determinasi di peroleh $\mathrm{r}^{2}=$ 0,06 artinya hanya $6 \%$ biaya produksi mempengaruhi ppatan usahatani kakao di Kecamatan Indra Makmur, dan $94 \%$ dipengaruhi oleh faktor lain seperti harga, motivasi, jumlah produksi yang peroleh, penyuluhan dan lain sebagainya.

\section{DAFTAR PUSTAKA}

Alma. 2005. Manajemen Pemasaran dan Pemasaran Jasa. CV. Alfabeta. Bandung.

Daniel. 2012. Kakao Komoditas, Potensial Pengembangan Ekonomi Kerakyatan. Sumatera Barat.

Daniel. 2002. Pengantar Ekonomi Pertanian. PT Bumi Aksara, Jakarta.

Gustiyana. 2004. Analisis Pendapatan Usahatani untuk Produk Pertanian. Salemba Empat. Jakarta.

Halim, Abdul. 2000. Akuntansi Manajemen. BPFE. Yogyakarta.

Hernanto. 2000. Ilmu Usahatani. Penebar Swadaya. Jakarta.

Laksana. 2008. Manajemen Pemasaran. Graha Ilmu. Yogyakarta.

Mulyadi. 2009. Akuntansi Biaya. Aditya Media. Yogyakarta.

Musa, Mohammad. 2008. Metode Penelitian. Jakarta: C.V Fajar Agung.

Soekartawi. 2002. Prinsip Dasar Manajemen Pemasaran Hasil Pertanian teori dan Aplikasi. Rajawali Press. Jakarta.

Sudjana. 2005. Statistika. Tarsito. Bandung. 
Sugiyono. 2008. Metode Penelitian Kuantitatif dan Kualitatif $R$ dan $D$. Alfabeta. Bandung.

Umar. 2001. Metode Penelitian. PT. Raja Grafindo Persada. Jakarta.

Wahyudi. 2008. Kakao: Manajemen Agribisnis dari Hulu Hingga Hilir. Penebar Swadaya. Jakarta.

Yamanto. 2000. Harga dan Penetapan Harga. CV. Mandar. Bandung. 